\title{
A filosofia hermenêutica de Hans-Georg Gadamer e as escolhas orçamentárias de políticas públicas
}

\author{
Pedro Germano dos Anjos ${ }^{1}$
}

\begin{abstract}
Resumo O trabalho visa analisar o exercício do poder estatal concernente ao atendimento das necessidades públicas ínsitas na Constituição Federal de 1988 por meio da escolha regrada constitucionalmente e no nível orçamentário, identificando opções políticas dirigidas ao Poder Executivo de qualquer unidade da Federação. Para tanto, utiliza como marco metodológico a ontologia da compreensão de Hans-Georg Gadamer. As consequências dessa análise são variadas, sendo ineludível a assunção teórica e pragmática de que a compreensão do sentido dos textos constitucionais se dá por meio da fusão horizôntica entre tradição e destaque (consciência da história efeitual), com especial proeminência do estágio de aplicação da interpretação. Esse estágio, a ser transpassado pelo administrador e pelo jurista que estiver diante das escolhas orçamentárias realizadas por aquele, é essencial para os devidos planejamento e consecução das políticas públicas. Ademais, é feita a comparação entre a relatividade das interpretações (Gadamer) e a relatividade dos direitos constitucionais (Robert Alexy), com importantes consequências no âmbito das escolhas orçamentárias. A perspectiva inédita deste trabalho, pois, revela-se fulcral para fundamentar tanto a determinação pelo Judiciário de imprescindíveis tarefas estatais quanto o controle social dos gastos públicos, lastreados no respeito à Lei do Orçamento.
\end{abstract}

Palavras-chave: Hermenêutica filosófica. Interpretação jurídica. Escolhas orçamentárias. Políticas Públicas. Orçamento Público.

\section{Introdução}

O trabalho de Hans-Georg Gadamer, importante hermeneuta do séc. XX, foi contribuição de grande valia para a filosofia e a hermenêutica contemporâneas, pelo que desenvolveu em relação aos aspectos da fenomenologia de Husserl e principalmente da de Heide-

\footnotetext{
${ }^{1}$ Mestrando em Direito Público pela Universidade Federal da Bahia - UFBa. Pesquisador vinculado à Fundação de Amparo a Pesquisa do Estado da Bahia - FAPESB. Pós-graduando em direito tributário pelo Instituto brasileiro de estudos tributários - IBET. pedro_jus@hotmail.com
} 
gger, ao tempo em que colocou em termos a relatividade das possíveis interpretações sobre os textos, atuando contra o extremo positivismo e as suas verdades empíricas absolutas.

Deve-se a Gadamer a estrutura dialógica da comunicação e a compreensão do ser humano da realidade (sempre linguística) que o cerca, da qual retira ininterruptamente elementos auxiliadores da própria compreensão desta e, logo, da compreensão de si mesmo.

O fenômeno jurídico é uma realidade linguística, ${ }^{2}$ como bem expõe Von Wright, para quem a formulação da norma-prescrição em linguagem é chamada de promulgação (linguagem aqui em sentido amplo). Norma e formulação divergem. ${ }^{3}$

Cuando la norma es una prescripción, la promulgación de la norma, es decir, el dar a conocer a los sujetos de la norma su caráter, contenido, y condiciones de aplicación, es un eslabón esencial en (o parte de) el processo a través del cual esta norma se origina o cobra existencia (ser). [...] La ejecución verbal es, además, necesaria para el establecimento de la relación entre la autoridad de la norma y el sujeto de la norma y del que hace la promesa y el que la recibe. Por la razón mencionada, las prescriciones puede decirse que dependen del lenguage. ${ }^{4}$ (grifo nosso).

Assim, do processo hermenêutico referido por Gadamer, não poderia o direito fugir. Envolve-se na atividade jurídica um processo de compreensão de textos normativos, a fim de aplicá-los aos diversos setores da vida, dada que essa é a finalidade última do direito: regrar as práticas sociais, sendo ele mesmo uma das práticas sociais. $^{5}$

Nessa esfera do direito, não são poucos os doutrinadores que salientam a importância da interpretação. Longe de corroborar com o conhecido brocardo 'in

\footnotetext{
${ }^{2}$ Para Paulo de Barros Carvalho, com nítida influência kelseniana, o direito é discurso prescritivo posto de forma técnica e discurso descritivo posto de forma científica. CARVALHO, Paulo de Barros. Curso de direito tributário. 19. ed. São Paulo: Saraiva, 2008. p. 2-8.

${ }^{3}$ WRIGHT, Georg Henrik Von. Norma y accion: una investigación lógica. Tradução de Pedro Garcia Ferrero. Madrid: Tecnos, 1970. p. 109.

${ }^{4}$ WRIGHT, Georg Henrik Von. Norma y accion: una investigación lógica. Tradução de Pedro Garcia Ferrero. Madrid: Tecnos, 1970. p. 110.

${ }^{5}$ Direito como prática social: DWORKIN, Ronald. O império do direito. Tradução de Jefferson Luiz Camargo. São Paulo: M. Fontes, 2007. p. 88-89.
} 
luminis cessat interpretatio, autores como Alf Ross, ${ }^{6}$ Karl Larenz, ${ }^{7}$ Ronald Dworkin ${ }^{8}$ e Robert Alexy asseveram a sua necessidade na aplicação de todos os textos legais, unindo a essa tarefa interpretativa a tarefa argumentativa: o conceito de norma é semântico. ${ }^{9}$

Aliás, como precursor, tem-se o próprio Hans Kelsen, o qual apregoou a existência de um quadro de normas aplicáveis a ser construído pela Ciência do Direito, a partir da interpretação dos textos legais. O quadro seria um rol de possíveis normas, interpretações, diante do texto a ser aplicado. ${ }^{10}$

Mas o papel da interpretação na teoria de Kelsen não é fundante, uma vez que ele privilegia o momento da aplicação do direito como ato de vontade, em prejuízo da explicação sobre o modo de produção do ato de conhecimento, o modus da interpretação (sem deixar de ser criticado principalmente nesse ponto).

A hermenêutica filosófica de Gadamer, por outro lado, requer mais do que um papel preliminar de apenas indicação das possíveis interpretações. Requer uma posição hermenêutica criativa diante dos problemas jurídicos: o momento de aplicação.

O corte epistemológico do presente trabalho é a análise da base hermenêutica do momento da aplicação do direito, sendo feitas breves considerações sobre a aplicação das normas constitucionais concernentes às necessidades públicas, ou, mais propriamente, dos direitos sociais, os quais preconizam um papel ativo do Estado de implementação.

\footnotetext{
${ }^{6}$ ROSS, Alf. Direito e justiça. Tradução de Edson Bini. São Paulo: Edipro, 2000. p. 184-185.

7 LARENZ, Karl. Metodologia da ciência do direito. 4. ed. Lisboa: Fundação Calouste Gulbenkian, 2005.

8 DWORKIN, Ronald. Levando os direitos a sério. Tradução Jefferson Luiz Camargo. São Paulo: M. Fontes, 2007. p. 40, 64. Também: DWORKIN, Ronald. O império do direito. Tradução de Jefferson Luiz Camargo. São Paulo: M. Fontes, 2007. p. 81-82.

9 ALEXY, Robert. Teoria dos direitos fundamentais. Tradução de Virgílio Afonso da Silva. São Paulo: Malheiros, 2008. p. 53-54. (Teoria e Direito Público).

${ }^{10}$ KELSEN, Hans. Teoria pura do direito. 6. ed. Tradução de João Batista Machado. São Paulo: M. Fontes, 1998. p. 390-391.
} 


\section{Natureza política das escolhas orçamentárias}

O Estado é uma organização social preordenada a certos fins, e para tanto exerce atividade financeira, entendida por Aliomar Baleeiro como consistente em "obter, criar, gerir e despender o dinheiro indispensável às necessidades, cuja satisfação o Estado assumiu ou cometeu aqueloutras pessoas de direito público". ${ }^{11}$

Refere-se o professor às necessidades públicas, cuja satisfação o Estado sempre avoca, assumindo a execução por si mesmo ou cometendo a outras pessoas de direito público (Administração Indireta). Vale observar, ademais, que, atualmente, o ordenamento jurídico permite a delegação de serviço público em que pessoas de direito privado exercem função pública.

Seguindo o raciocínio de que é impossível atender a todas as necessidades públicas existentes em uma comunidade em apenas um governo, o ordenamento jurídico-constitucional preconiza o dever do Poder Executivo em indicar as necessidades a serem satisfeitas prioritariamente.

Nesse sentido, a natureza das escolhas das necessidades públicas é política. Sobre essa natureza, escreve José Souto Maior Borges ${ }^{12}$ que:

[...] variáveis motivos políticos e que não podem ser determinados a priori comandam a atuação do Estado no sentido de promover a satisfação de certas necessidades coletivas, exercendo os governos uma série constante de opções das necessidades sociais a serem satisfeitas pela rede de serviços públicos.

Nessa esteira, também Aliomar Baleeiro: ${ }^{13}$

Determinar quais as necessidades de um grupo social a serem satisfeitas por meio do serviço público, e, portanto, pelo processo da despesa pública, ressalvada a hipótese de concessão, constitui missão dos órgãos políticos e questão essencialmente política.

${ }^{11}$ BALEEIRO, Aliomar. Uma introdução à ciência das finanças. 16. ed. rev. e atual. por Dejalma de Campos. Rio de Janeiro: Forense, 2006. p. 4.

${ }^{12}$ BORGES, José Souto Maior. Introdução ao direito financeiro. São Paulo: M. Limonad,1998. p. 13-14.

${ }^{13}$ BALEEIRO, Aliomar. Uma introdução à ciência das finanças. 16. ed. rev. e atual. por Dejalma de Campos. Rio de Janeiro: Forense, 2006. p. 78. 
Para a escolha das necessidades, a Constituição Federal de 1988 prescreve obrigações de fazer ao Estado, como obrigações mínimas a cumprir. ${ }^{14}$ Por outro lado, a mesma Constituição regula um dos elementos da atividade financeira do Estado: o planejamento. $\mathrm{O}$ administrador deve proceder à realização de um orçamento, prevendo as necessidades que deseja satisfazer, especificamente (art. 165, C.F.).

O problema hermenêutico que ora se debruça é quanto à noção exata das necessidades públicas estatais impostas à Constituição. Não se sabe o limite do dever do administrador público frente aos deveres constitucionais, ou se realmente há limite (qual interpretação deve ser dada à Constituição).

Por outro lado, outro problema é tal que, sendo legítima a escolha orçamentária, até onde ela pode não ser modificada pelo administrador (mudança de interpretação). A solução a tais questionamentos será iluminada diante de algumas considerações de Hans-Georg Gadamer quanto à compreensão, analisadas a seguir.

A par de todas as considerações feitas sobre o dever ao orçamento, pode-se realizar uma comparação frutífera no âmbito teórico, mas que não deixa de ter consequências práticas relevantes com a filosofia hermenêutica de Hans Georg Gadamer.

Toda comparação teorética necessita, pois, de uma justificativa de coerência. A razão mais clara da aproximação do direito orçamentário com a teoria hermenêutica de Gadamer é, segundo preconizado neste trabalho, a historicidade da compreensão, a temporalidade do ser tal como se mostra a si mesmo (aletheia) e a estrutura compreensiva feita por Gadamer no tocante ao estágio da aplicação.

Como a coerência da comparação necessita fundamentar a base teórica para a caracterização das necessidades públicas ínsitas de um documento orçamentário e, logo, o início de um pensar sobre as relações jurídicas de direito orçamentário que se formam entre Estado e comunidade (e, na perspectiva aplicativa, incluindo-se o Poder Judiciário), mister debater aqueles pontos da filosofia hermenêutica.

\footnotetext{
${ }^{14}$ Fala-se em deveres explícitos do Estado, como dos artigos 205, 215, 217, 225, 226, 227 e 230.
} 


\section{Hermenêutica filosófica de Hans-Georg Gadamer}

\subsection{Influência da fenomenologia de Martin Heidegger}

Hans-Georg Gadamer foi discípulo de Martin Heidegger, pensador alemão, o qual por sua vez teve como professor Edmund Husserl. Heidegger, a partir de estudos críticos ao idealismo alemão e sob os auspícios do pensamento fenomenológico de Husserl, inaugurou uma nova vertente do pensamento filosófico: a fenomenologia heideggeriana.

Diz-se "heideggeriana", tanto porque a fenomenologia de Martin Heidegger possui conceitos próprios e se refere ao fenomenológico de maneira muito peculiar, quanto pela sua cisão com o pensamento de seu próprio professor, Husserl, de quem foi assaz crítico, posteriormente ao período acadêmico.

A fenomenologia começa em Husserl, no século XIX, por meio das Investigações Lógicas (1900-1901), cujo objetivo era colocar a fenomenologia como busca da 'lógica pura', de um lado na descrição da generalidade da essência, de outro lado na revelação das fontes dos conceitos fundamentais (atos conscientes).

O pensamento pioneiro de Husserl, no entanto, possui dissonância interna sobre o papel do psicologismo em relação à lógica e uma origem incoerentemente metafísica (para quem propugnava criticar a tradição metafísica da ciência) do embasamento transcendental que Husserl chegou a apregoar ao mundo da vida.

O esforço dele em construir uma fenomenologia transcendental para afastar da filosofia as tentativas positivistas psicologistas, historicistas e materialistas era visto como uma recaída no idealismo kantiano, ao tempo em que as suas preferências pelas análises da subjetividade eram vistas como um risco à objetividade científica. ${ }^{15}$

Essas incongruências originaram uma série de escolas filosóficas que se posicionavam de forma diferente ante a teoria fenomenológica de Husserl. Ernildo Stein as agrupou em cinco principais, sendo que Heidegger exerceu influência

${ }^{15}$ STEIN, Ernildo. Compreensão e finitude: estrutura e movimento da interrogação heideggeriana. Ijuí, RS: Unijuí, 2001. p. 141. (Ensaios: política e filosofia). 
direta em pelo menos duas delas: a fenomenologia transcendental, na Universidade de Freiburg, orientando de qualquer modo a fenomenologia hermenêutica da Universidade de Marburgo, com seus seguidores Gadamer e Kuhn, dentre outros. ${ }^{16}$

No que toca às considerações deste trabalho, vale expor alguns pontos do entendimento de Heidegger que influenciaram sobremaneira o pensamento de Gadamer sobre a hermenêutica.

Diz Stein que a problemática ontológica estava muito mais presente em Heidegger que nas sistematizações de Husserl. O primeiro, no contato com o segundo, mais foi se afastando da metafísica ocidental: "o problema do ser que lhe vinha de Aristóteles e o método fenomenológico de o abordar que lhe vinha de Husserl instauraram um outro horizonte de interrogação no ânimo de Heidegger". ${ }^{17}$

O sentido e o alcance da fenomenologia eram, para Heidegger, as coisas em si mesmas, no aspecto temporal. Inclui-se a análise do próprio ser que analisa: o homem. Sucintamente, sobre as premissas de Heidegger pode ser dito que: o ser é coisa em si mesmo, porém o ser se dá com o tempo (se desvela e se vela). A filosofia deve captar o ser como velamento e desvelamento pelo método fenomenológico e no horizonte do tempo (porque o ser apenas se dá no tempo). Como a assumir que o ser essência é inacessível, centra a análise do ser ligado no tempo a partir do ente em que o tempo é o seu sentido: trata-se do ser-aí (ente).

De outro lado, o único ente cujo ser consiste em compreender o ser é o homem. Logo, interrogar pelo ser no tempo e partir da temporalidade do ser-aí é movimentar-se na finitude, compreender o ser fora da tradição metafísica.

A interrogação de Heidegger é ontológica na medida em que investiga a finitude do ser-aí e do ser, pois o ser-aí é constituído por seu movimento no ser, enquanto o ser nele se manifesta e enquanto o ser o sustenta.

Diferiu de Husserl porque esse último acompanha o pensamento ontoteológico da tradição metafísica, no sentido da redução transcendental. Outro ponto de dissonância se encontra na concepção de mundo da vida (ser no mundo): para

${ }^{16}$ STEIN, Ernildo. Compreensão e finitude: estrutura e movimento da interrogação heideggeriana. Ijuí, RS: Unijuí, 2001. p. 140. (Ensaios: política e filosofia).

${ }^{17}$ STEIN, Ernildo. Compreensão e finitude: estrutura e movimento da interrogação heideggeriana. Ijuí, RS: Unijuí, 2001. p. 146. (Ensaios: política e filosofia). 
Heidegger é o ponto de partida para a interrogação ontológica (objeto de análise para descobrimento do ser-aí); para Husserl é um dos fundamentos da redução transcendental.

Sobre o ser-aí, é o ente que se dá na facticidade. Isso faz com que ele seja irredutível a uma total transparência reflexiva. Sua facticidade é existência e por isso não se pode reduzi-lo a uma essência.

A análise do ser-aí como ser no mundo deveria mostrar como ele, em sua determinação ontológica, jamais se esgota na pura objetivação. O ser-aí vem sempre envolto na autenticidade e inautenticidade, na verdade e na não verdade, no velamento que acompanha todo o desvelamento. Dessa maneira, a fenomenologia não será mais o instrumento de redução de tudo à subjetividade, nem um caminho que deve transformar tudo em 'objeto'. A fenomenologia heideggeriana mergulhará no seio do velamento e desvelamento em que residem todas as essências. Esse âmbito é o lugar em que se dá a abertura no ser-aí. ${ }^{18}$

Heidegger utiliza a construção grega de aletheia e de apophainesthai. Sucintamente, aletheia é a perspectiva de que o verdadeiro ser se vela no ser-aí, ou seja, se vela no seu desvelamento. Contra a metafísica tradicional, o ser não é o ente objetivado, estudado pelos métodos da ciência natural, mas é aquilo que se vela no desvelamento, constituindo, apesar disso, aquilo que alimenta o fenômeno, sem o que o fenômeno não existiria.

A análise do discurso apofântico é aqui utilizada para clarificar a concepção de aletheia: o discurso torna evidente uma ideia (aquilo de que se fala), e sua realização concreta acontece na linguagem (logos como apophansis). Sem a ideia (ser) não há que se falar em discurso (ser-aí), sendo precisamente papel da hermenêutica descobrir aspectos da ideia a partir do discurso.

Segundo observa Richard Palmer, devido a Heidegger, a hermenêutica passa a se referir à explicação fenomenológica da própria existência humana. A análise de Heidegger indicou que a 'compreensão' e a 'interpretação' são modos fundamentais da existência humana, apresentando uma ontologia da compreensão. A sua investigação é de caráter hermenêutico, quer nos conteúdos, quer no método.

${ }^{18}$ STEIN, Ernildo. Compreensão e finitude: estrutura e movimento da interrogação heideggeriana. Ijuí, RS: Unijuí, 2001. p. 153. (Ensaios: política e filosofia). 
“A hermenêutica é relacionada de uma só vez com as dimensões ontológicas da compreensão (e com tudo aquilo que isso implica) e simultaneamente com a fenomenologia especifica de Heidegger." ${ }^{19}$

Outro indicador em Heidegger do que seja a função da hermenêutica é a ambivalência do ser (consequência da aletheia), comentada por Heidegger quando remete a Aristóteles: a alma, que constitui o ser do homem, descobre em seus modos de ser todo ente naquilo que ele é e como ele é, ou seja, descobre sempre todo ente em seu ser. Assim, para Heidegger, o primado ôntico-ontológico da questão do ser funda-se na indicação provisória do primado ôntico-ontológico da presença (ser-aí). ${ }^{20}$

A presença mostrou-se, assim, como o ente que deve ser trabalhado e desenvolvido em seu ser de maneira suficiente para que o questionamento se torne transparente. Agora, porém, revelou-se que a analítica ontológica da presença em geral constitui a ontologia fundamental e que, portanto, a presença se evidencia como o ente a ser, em princípio, previamente interrogado em seu ser. ${ }^{21}$

Por sua vez, observa Ernildo Stein que, para Heidegger, a ontologia que parte das estruturas do ser-aí deve ter como método a fenomenologia, no que concretizada na hermenêutica:

O logos da fenomenologia do ser-aí tem o caráter de hermeneuein que anuncia à compreensão do ser, incluso no ser-aí, o sentido autêntico do ser em geral e as estruturas fundamentais de seu próprio ser. ${ }^{22}$

Assim, Heidegger procede a uma revisão do uso da hermenêutica, retornando ao uso grego da palavra hermeneuen - exposição [de Hermes] que comunica a mensagem dos deuses. ${ }^{23}$ Assim, o hermenêutico não é explicação, mas é o

${ }^{19}$ PALMER, Richard E. Hermenêutica. Tradução de Maria Luisa Ribeiro Ferreira. Lisboa: Edições 70, 2006. p. 51. (O saber da filosofia).

${ }^{20}$ HEIDEGGER, Martin. Tempo e ser. 3. ed. Petrópolis: Vozes, 2008. p. 50. (Pensamento Humano).

${ }^{21}$ HEIDEGGER, Martin. Tempo e ser. 3. ed. Petrópolis: Vozes, 2008. p. 51. (Pensamento Humano).

${ }^{22}$ STEIN, Ernildo. Compreensão e finitude: estrutura e movimento da interrogação heideggeriana. Ijuí, RS: Unijuí, 2001. p. 187. (Ensaios: política e filosofia).

${ }^{23}$ Detalhamento sobre esse sentido de hermeneuen, ver PALMER, Richard E. Hermenêutica. Tradução de Maria Luisa Ribeiro Ferreira. Lisboa: Edições 70, 2006. p. 24-30. (O saber da filosofia). 
trazer da mensagem, da comunicação. Aqui, um ponto que Gadamer desenvolve na dialética da pergunta e no papel da tradição no processo de compreensão, como se verá adiante.

Hermenêutica é, por isso, em Heidegger, a ontologia da compreensão. A compreensão possui existencialidade: o ser-aí é hermenêutico, enquanto nele reside uma pré-compreensão do ser: a compreensão é o modo de ser do ser-aí enquanto existência.

Sobre o assunto, Paul Ricoeur ensina que um dos modos de fundamentar a hermenêutica na fenomenologia é por meio da ontologia da compreensão, à maneira de Heidegger. A compreensão é vista como modo de ser, não só de mero conhecimento, pois a questão se inverte: em vez de procurar o método para a compreensão, questiona-se o que é a compreensão. "O problema hermenêutico tornase, desse modo, um problema da analítica deste ente, o Dasein, que existe através da compreensão."24

Por isso, a condição do ser-aí que já sempre compreende em seu ser revela os sentidos de hermenêutica em Heidegger: explicitação, elaboração das condições de possibilidade de análise ontológica, analítica da existência e metodologia das Geisteswissenschaften.

De qualquer modo, a questão hermenêutica em Heidegger lembra, desde o início, que, para a compreensão do ser-aí, deve-se proceder a um exame prévio da questão do sentido do ser em geral. É necessária uma ideia prévia do próprio ser. Daqui, parte importante ponto para a 'descoberta' de Gadamer da pré-compreensão.

Ernildo Stein ainda aduz: "O desvelamento do hermenêutico no ser-aí, pela analítica existencial, é o ponto de partida necessário para a ontologia. Esse princípio [hermenêutico] caracteriza toda a obra de Heidegger". ${ }^{25}$

Do contato com o pensamento de Heidegger, ainda se pode dizer que, entre ser e ser-aí, há uma diferença ontológica. A apreensão dessa diferença, no entanto,

\footnotetext{
${ }^{24}$ RICOEUR, Paul. Existência e hermenêutica. In: BLEICHER, Josef. Hermenêutica contemporânea. Tradução de Maria Georgina Segurado. Rio de Janeiro: Edições 70, 1980. p. 331.

${ }^{25}$ STEIN, Ernildo. Compreensão e finitude: estrutura e movimento da interrogação heideggeriana. Ijuí, RS: Unijuí, 2001. p. 193-194. (Ensaios: política e filosofia).
} 
pelo homem, apenas se dá em termos de linguagem: a linguagem seria a casa do ser, pois esse acontece como fenômeno na linguagem. ${ }^{26} \mathrm{O}$ papel da linguagem em Gadamer é muito relevante, como medium da experiência hermenêutica.

\subsection{A ontologia da compreensão}

Afirma Richard Palmer que Gadamer reuniu em uma obra o esforço de escalonação da hermenêutica com a estética e com a filosofia do conhecimento histórico, retratando parte do pensamento hermenêutico de Hegel e Heidegger, no conceito de consciência 'historicamente operativa', atuando dialeticamente com a tradição enquanto transmitida por meio do texto.

Ainda segundo Palmer, a hermenêutica notadamente com Gadamer entra na fase linguística, sendo o encontro do Ser por meio da linguagem. A própria realidade humana é linguagem e a hermenêutica não poderia afastar-se das questões epistemológicas e ontológicas, pois a compreensão é um tema epistemológico e ontológico. ${ }^{27}$

O espectro do pensamento hermenêutico contemporâneo, porém, possui nítida polarização. De um lado, seguidores de Schleiermacher e Dilthey, como Emilio Betti, encarando a hermenêutica como corpo geral de princípios metodológicos que subjazem à interpretação. De outro, discípulos de Heidegger, a exemplo de Hans-Georg Gadamer, encarando a hermenêutica como exploração filosófica das características e dos requisitos necessários a toda e qualquer compreensão.

Betti defende a possibilidade de objetividade na interpretação das interpretações válidas, enquanto Gadamer compreende a interpretação como filosofia, sendo a compreensão um ato histórico e, como tal, necessariamente relacionada com o presente. ${ }^{28}$

\footnotetext{
${ }^{26}$ STEIN, Ernildo. Compreensão e finitude: estrutura e movimento da interrogação heideggeriana. Ijuí, RS: Unijuí, 2001. p. 197. (Ensaios: política e filosofia).

${ }^{27}$ PALMER, Richard E. Hermenêutica. Tradução de Maria Luisa Ribeiro Ferreira. Lisboa: Edições 70, 2006. p. 51-52. (O saber da filosofia).

${ }^{28}$ PALMER, Richard E. Hermenêutica. Tradução de Maria Luisa Ribeiro Ferreira. Lisboa: Edições 70, 2006. p. 55. (O saber da filosofia).
} 
Betti e Hirsch afirmam que o estudo da história implica o abandono do ponto de vista atual do historiador, alegando que a hermenêutica deve fornecer princípios de uma interpretação objetiva. Gadamer sustenta, em autodefesa, que simplesmente descreve cada ato de compreensão, fazendo ontologia e não metodologia.

Do ponto de vista de Betti, Heidegger e Gadamer são os críticos destrutivos da objetividade, que pretendem mergulhar a hermenêutica num pântano de relatividade, sem quaisquer regras. É a integridade do próprio conhecimento histórico que está a ser atacada e é preciso defendê-la com firmeza. ${ }^{29}$

Por outro lado, decisivo é acentuar que a análise de Gadamer visa destruir da hermenêutica, como ciência do espírito, a vinculação estrita com a metodologia. Antes da sua obra, a hermenêutica tinha apenas esse aspecto, quase sempre subordinada à análise filológica e à indicação científica (uma pretensa neutralidade axiológica) dos cânones interpretativos.

Ideias como interpretação distorcida, círculo hermenêutico (no sentido de Schleiermacher) e a reconstrução do processo criativo do autor, 'melhor do que ele mesmo entendeu sua criação, subjazem a essa perspectiva eminentemente metodológica da hermenêutica.

Já Gadamer se refere à ontologia da compreensão, a partir de questões debatidas por Heidegger. A compreensão da verdade (a verdade de cada ponto de vista) por meio da linguagem sobrepõe-se à questão do método, em sua obra Verdade e Método, em dois volumes.

Por outro lado, como salienta Josef Bleicher,

A consideração de uma realidade projetada ou evidenciada, digamos, por um texto, liga a hermenêutica crítica à filosofia hermenêutica, que salientou a função da obra de arte na abertura de um 'mundo' diante de nós, em oposição a qualquer preocupação com a psicologia do autor. ${ }^{30}$

${ }^{29}$ PALMER, Richard E. Hermenêutica. Tradução de Maria Luisa Ribeiro Ferreira. Lisboa: Edições 70, 2006. p. 56. (O saber da filosofia).

${ }^{30}$ BLEICHER, Josef. Hermenêutica contemporânea. Tradução de Maria Georgina Segurado. Rio de Janeiro: Edições 70, 1980. p. 354. 
Além de ir de encontro ao uso do método das ciências naturais, ou um seu correspondente (ao modo de Dilthey), no estudo das Geisteswissenschaften, Gadamer formula uma teoria hermenêutica desvencilhada da análise psicológica do autor a partir da sua obra, como chegou a apregoar Schleiermacher. Logo se vê que o referido autor alemão se afasta da hermenêutica romântica ou, simplesmente, da hermenêutica como método.

Essas duas frentes de combate se justificam; primeiro em razão da formulação ontológica da compreensão, a qual não pode alcançar, seguramente e sem preconceitos próprios, a vontade psicológica do autor. Paul Ricoeur critica a busca hermenêutica pela vontade do autor, aduzindo que a compreensão não se liga ao autor e sua situação, mas em apreender as posições de mundo descortinadas pela referência do texto. ${ }^{31}$

Ainda, e com apoio em Gadamer, anote-se que a suposta vontade psicológica do autor é produto da tradição, do processo de destaque e de preconceitos do próprio intérprete, não havendo razão para que seja considerada como pauta de validação das interpretações, como querem Betti e Hirsch. ${ }^{32}$ Segundo, porque o modo de construção ontológica da compreensão em Gadamer rechaça opiniões absolutistas quanto à sua verdade, justamente a pretensão das ciências naturais, por meio do seu método objetivista.

A filosofia hermenêutica alertou-nos para o perigo do objetivismo subjacente à abordagem metódica, objetivamente, da interpretação das expressões humanas. Ao desenvolvermos o nosso conhecimento da 'pré-estrutura' da compreensão, excluímos ainda a pressuposição simplista da possibilidade de um conhecimento totalmente objetivo ou neutro, dado o fato de termos já interpretado um objeto 'como' algo, antes mesmo de o chegarmos a investigar. ${ }^{33}$

${ }^{31}$ RICOEUR, Paul. Teoria da interpretação: o discurso e o excesso de significação. Tradução de Artur Morão. Lisboa: Edições 70, 1980. p. 99.

32 Para Hirsch o sentido verbal pretendido pelo autor é norma, sendo até um sentido imutável, reprodutível e fixo. Acaba ele numa 'filologia da busca da intenção do autor.' PALMER, Richard E. Hermenêutica. Tradução de Maria Luisa Ribeiro Ferreira. Lisboa: Edições 70, 2006. p. 69-70. (O saber da filosofia).

${ }^{33}$ BLEICHER, Josef. Hermenêutica contemporânea. Tradução de Maria Georgina Segurado. Rio de Janeiro: Edições 70, 1980. p. 353. 
Isso se deve ao fato, crê-se, à influência de Heidegger quanto à crítica à tradição metafísica da análise do ente como ser. O conhecimento objetivo da ciência natural é meramente a descrição de fenômenos subjugados à perspectiva exclusiva da apreensão sensível.

Para Heidegger, a metafísica não trata de investigar os fenômenos no sentido fenomenológico (o desvelamento que vela o ser), mas tão somente os fenômenos sensíveis, os quais em si não são desvelamentos e por isso não se prestam à descoberta do Ser. ${ }^{34}$

De outro lado, é possível ainda apontar como aliados de Gadamer os teólogos da desmitologização e da 'Nova hermenêutica', como Bultmann, Ebeling e Fuchs, graças à abordagem essencialmente heideggeriana e fenomenológica. ${ }^{35}$

Bultmann aproxima-se, apesar de considerar a hermenêutica como teoria da exegese, em razão da desmitologização ser projeto hermenêutico de interpretação existencial. Enleva-se o autoconhecimento como objetivo da linguagem do novo testamento, no sentido de kerygma (palavra das palavras para Heidegger) que significa autocompreensão existencial.

Já Ebeling e Fuchs também centram a análise no problema hermenêutico, mas o fazem adotando a linguística: não é meramente o ajuste do texto à realidade que Bultmann proclama em termos de uma autocompreensão existencial, trata-se de analisar como uma palavra (evento) que aconteceu pode ser hoje compreendida. ${ }^{36}$

Interessante notar que Paul Ricoeur também coloca a questão da palavra evento, a partir da dialética, própria do discurso (fala), de evento e significação. Já que conseguimos transpassar pela história uma mensagem (mesmo que não unívoca, em razão da equivocidade), o evento palavra (sentido de discurso) não é

${ }^{34}$ HEIDEGGER, Martin. Tempo e ser. 3. ed. Petrópolis: Vozes, 2008. (Pensamento Humano). p. 39-40. Comentários sobre isso em STEIN, Ernildo. Compreensão e finitude: estrutura e movimento da interrogação heideggeriana. Ijuí, RS: Unijuí, 2001. p. 229-330. (Ensaios: política e filosofia).

${ }^{35}$ PALMER, Richard E. Hermenêutica. Tradução de Maria Luisa Ribeiro Ferreira. Lisboa: Edições 70, 2006. p. 56. (O saber da filosofia).

${ }^{36}$ PALMER, Richard E. Hermenêutica. Tradução de Maria Luisa Ribeiro Ferreira. Lisboa: Edições 70, 2006. p. 61. (O saber da filosofia). 
evento totalmente evanescente, perdido no tempo, mas se perpetua no conjunto de significações possíveis: “ao longo de todas as transformações, preserva uma identidade própria que pode chamar-se o conteúdo proposicional, o dito enquanto tal". ${ }^{37}$

Acompanhando o corte epistemológico do presente trabalho, é necessário aduzir algumas premissas de Gadamer quanto ao processo de compreensão, para além das já mencionadas, as quais são importantes para a análise hermenêutica das escolhas orçamentárias.

\subsection{Fusão horizôntica}

Segundo Hans-Georg Gadamer, a hermenêutica trata de se orientar à compreensão ao sentido do próprio texto, e isso interessa em distinguir a pergunta sobre o que deveria o texto responder da pergunta sobre o que ele efetivamente responde. A reconstrução das ideias do autor é uma tarefa completamente diferente. ${ }^{38}$

Caracteriza a história efeitual para combater a busca da opinião do autor: toda atualização da compreensão pode ser encarada como possibilidade histórica do compreendido, sendo que essa compreensão se altera conforme a diferença de existência: haja vista a finitude histórica de nossa existência.

“A redução hermenêutica à opinião do autor é tão inadequada como nos acontecimentos históricos, a redução à intenção dos que atuam neles." ${ }^{39}$ A reconstrução da pergunta não é produto puro da história, mas a ela subjaz primeiro a pergunta que o texto nos coloca: frente à tradição, de modo que a sua compreensão implica sempre a tarefa de automediação histórica com a tradição.

O transmitido que nos fala coloca ele próprio a pergunta e situa, portanto, a nossa opinião no aberto (incitamento da obra em nós). Para responder, temos que interrogar. Compreender uma palavra da tradição que nos afeta requer sempre pôr

\footnotetext{
${ }^{37}$ RICOEUR, Paul. Teoria da interpretação: o discurso e o excesso de significação. Tradução de Artur Morão. Lisboa: Edições 70, 1980. p. 21.

${ }^{38}$ GADAMER, Hans-Georg. Verdade e método: traços fundamentais de uma hermenêutica filosófica. Tradução de Flávio Paulo Meurer. 3. ed. Petrópolis: Vozes, 1999. v. 1. p. 548.

${ }^{39}$ GADAMER, Hans-Georg. Verdade e método: traços fundamentais de uma hermenêutica filosófica. Tradução de Flávio Paulo Meurer. 3. ed. Petrópolis: Vozes, 1999. v. 1. p. 549.
} 
a pergunta reconstruída no aberto de sua questionabilidade: passar à pergunta o que a tradição vem a ser para nós.

Nesse processo histórico, a pergunta é um já não compreender mais. Por outro lado, faz parte da própria compreensão o recuperar os conceitos de um passado histórico de maneira que contenham o nosso próprio conceber. Gadamer chama isso de fusão de horizontes.

$\mathrm{Na}$ hermenêutica, Gadamer identifica que há um retrocesso à intenção imediata da coisa que na compreensão é posta em suspenso: é a pergunta. Perguntar permite sempre ver as possibilidades que ficam em suspenso. Compreender a questionabilidade de algo é, antes, sempre perguntar, provando as possibilidades de sentido. "Aquele que quer pensar tem de perguntar." 40

Tal é a razão pela qual todo compreender é sempre algo a mais que um simples reproduzir uma opinião alheia. Quando se pergunta, deixam-se abertas possibilidades de sentido, de maneira que aquilo que tenha sentido possa ser introduzido na própria opinião. [...] Isto significa então que compreendemos como foram colocadas determinadas perguntas sob certas condições históricas. Compreender uma pergunta quer dizer perguntá-la. Compreender uma opinião quer dizer compreendê-la como resposta a uma pergunta. (grifo nosso). ${ }^{41}$

Gadamer indica que a lógica da pergunta e resposta, inclusive, tende a acabar com o tema do problema. Podem ser vistos os problemas não como perguntas insolúveis, mas como alternativas de opinião que somente admitem um tratamento dialético, com lugar na retórica.

Por outro lado, a dialética da pergunta e resposta permite a determinação da classe de consciência que é a consciência efeitual, pois permite que a relação da compreensão se manifeste como uma relação recíproca, semelhante à de uma conversação. Se o texto não nos fala como um $t u$, nós compreendemos o que trazemos à fala a partir de nós. Mas esse trazer a partir de nós não é uma intervenção arbitrária: está referida, enquanto pergunta, à resposta latente

${ }^{40}$ GADAMER, Hans-Georg. Verdade e método: traços fundamentais de uma hermenêutica filosófica. Tradução de Flávio Paulo Meurer. 3. ed. Petrópolis: Vozes, 1999. v. 1. p. 551.

${ }^{41}$ GADAMER, Hans-Georg. Verdade e método: traços fundamentais de uma hermenêutica filosófica. Tradução de Flávio Paulo Meurer. 3. ed. Petrópolis: Vozes, 1999. v. 1. p. 552. 
no texto. "A latência de uma resposta pressupõe que aquele que pergunta é alcançado e interpelado pela própria tradição. Esta é a verdade da consciência da história efeitual".42

A consciência da experiência histórica, pelo que nega o fantasma de um esclarecimento total, está aberta à experiência da história, no modo de realização da fusão de horizontes do compreender.

Pois bem, Gadamer já indica o liame entre as partes dois e três do seu livro Verdade e Método, aduzindo que essa fusão de horizontes que se dá na compreensão (tratada na primeira) é o genuíno desempenho da linguagem (que será analisada na segunda). O problema é que a linguagem não é termo unívoco. Mas as suas considerações sobre a compreensão ser um diálogo uma conversação com nós mesmos, já indicam que a linguagem deve ser estudada.

Exemplifica o autor que, assim como o interlocutor se põe de acordo com outro em uma conversação, também o intérprete entende a coisa que lhe diz o texto. A compreensão ocorre necessariamente em forma linguística, mas não como revestimento de uma compreensão já feita, mas justamente no vir-à-fala da própria coisa. A pergunta é um momento hermenêutico, que abre a oportunidade do entendimento.

De outro lado, toda conversação constitui a partir de si uma linguagem comum, a fim de que haja um intercâmbio mútuo. Nessa linguagem comum, ambos entram gradualmente, à medida da conversação, sob a verdade da própria coisa, esta que reúne numa nova comunidade. "O acordo na conversação não é uma mera representação e impor o próprio ponto de vista, mas uma transformação rumo ao comum, de onde já não se continua sendo o que era.”

\subsection{As variáveis da compreensão}

Explica Gadamer, que a compreensão se dá por meio da fusão entre os horizontes da tradição (nela está o próprio texto) e o consequente destaque do intérprete. A pré-compreensão que o intérprete possui sobre determinado

${ }^{42}$ GADAMER, Hans-Georg. Verdade e método: traços fundamentais de uma hermenêutica filosófica. Tradução de Flávio Paulo Meurer. 3. ed. Petrópolis: Vozes, 1999. v. 1. p. 555. 
assunto influencia sobremaneira essa fusão, sendo o conjunto de preconceitos (em sentido específico) absorvido por determinado indivíduo por meio da tradição linguística. ${ }^{43}$

É desse modo que Gadamer sustenta a possibilidade de diferentes interpretações sobre o mesmo signo, a depender de três variáveis: a tradição linguística, o destaque e a necessidade de aplicação ao presente.

A primeira variável forma de maneira inconsciente no intérprete os preconceitos, os quais determinarão o espectro do destaque (situação suspensa do intérprete com relação à tradição recebida) e o espectro do horizonte do texto para determinado intérprete.

Sobre os preconceitos, é preciso salientar que Gadamer exalta Heidegger, pois este teria oferecido uma descrição correta “quando descobre no suposto 'ler' o que 'lá está' a pré-estrutura da compreensão". ${ }^{4}$ Trata-se de afastar tudo o que impede alguém de compreender a própria coisa, como as ideias prévias, os preconceitos não percebidos, os quais nos tornam surdos para a 'tradição' do texto.

Heidegger, zetético, teria questionado uma posição prévia da ontologia clássica - a interpretação de que o ser seria o ser atual e presente - e se mantido em uma posição prévia de zetética com as premissas ontológicas de subjetividade. "É assim que se mostra a concreção da consciência histórica, da qual se trata no compreender." 45

Identifica Gadamer a agudeza do problema hermenêutico: toda compreensão tem caráter essencialmente preconceituoso, até o historicismo, 'o preconceito contra os preconceitos enquanto tais'. Mas ele se refere ao preconceito no sentido de juízo prévio (que se forma antes de todos os momentos determinantes segundo a coisa): "no procedimento jurisprudencial um preconceito é uma pré-decisão

\footnotetext{
${ }^{43}$ GADAMER, Hans-Georg. Verdade e método: traços fundamentais de uma hermenêutica filosófica. Tradução de Flávio Paulo Meurer. 3. ed. Petrópolis: Vozes, 1999. v. 1. p. 559-560.

${ }^{44}$ GADAMER, Hans-Georg. Verdade e método: traços fundamentais de uma hermenêutica filosófica. Tradução de Flávio Paulo Meurer. 3. ed. Petrópolis: Vozes, 1999. v. 1. p. 405.

${ }^{45}$ GADAMER, Hans-Georg. Verdade e método: traços fundamentais de uma hermenêutica filosófica. Tradução de Flávio Paulo Meurer. 3. ed. Petrópolis: Vozes, 1999. v. 1. p. 406.
} 
jurídica, antes de ser baixada uma sentença definitiva". ${ }^{46}$ Para quem participa do processo, um preconceito como esse diminui as suas chances, o que advém o caráter negativo de preconceito. Mas em essência, preconceito é apenas o juízo prévio.

O movimento racionalista do iluminismo trouxe a ojeriza a dois tipos de preconceitos, quais sejam, o da autoridade e da precipitação de compreender. De qualquer modo, porém, devem ser confrontados com a razão. Apregoa Gadamer:

[...] a superação de todo preconceito, cuja revisão liberará primeiramente o caminho para uma compreensão adequada da finitude, que domina não apenas o nosso ser-homem, mas também a nossa consciência histórica. ${ }^{47}$

Aduz que não só o pensamento tradicional, assaz criticado pelo Aufklärung e pelo romantismo, está submetido a preconceitos: assim é toda a existência humana, não sendo uma possibilidade a razão absoluta. "Para nós a razão somente existe como real e histórica. Isso significa simplesmente: a razão não é dona de si mesma, pois está sempre referida ao dado no qual se exerce".48

A relatividade da razão não significa, entretanto, a sua desqualificação no processo de compreensão: o preconceito (juízo prévio) da autoridade da tradição (do que nos chega) é sempre posto em confronto com a razão histórica do intérprete.

O topos (ou a questão epistemológica fundamental) do problema hermenêutico é justamente o pré-juízo legítimo, tão rejeitado pelo movimento racionalista. Na verdade, ele, o preconceito legítimo, é parte integrante da própria realidade histórica, já que o peculiar modo de ser do homem é finito e histórico. ${ }^{49}$

Por intuir a existência de preconceitos justificados, Gadamer rejeita a fé metódica de Schleiermacher e do Aufkalärung. A fé na autoridade pode ser fonte de

${ }^{46}$ GADAMER, Hans-Georg. Verdade e método: traços fundamentais de uma hermenêutica filosófica. Tradução de Flávio Paulo Meurer. 3. ed. Petrópolis: Vozes, 1999. v. 1. p. 407.

${ }^{47}$ GADAMER, Hans-Georg. Verdade e método: traços fundamentais de uma hermenêutica filosófica. Tradução de Flávio Paulo Meurer. 3. ed. Petrópolis: Vozes, 1999. v. 1. p. 414.

${ }^{48}$ HABERMAS, Jürgen. A pretensão da hermenêutica à universalidade. In: BLEICHER, Josef. Hermenêutica contemporânea. Tradução de Maria Georgina Segurado. Rio de Janeiro: Edições 70, 1980. p. 415.

${ }^{49}$ GADAMER, Hans-Georg. Verdade e método: traços fundamentais de uma hermenêutica filosófica. Tradução de Flávio Paulo Meurer. 3. ed. Petrópolis: Vozes, 1999. v. 1. p. 416. 
verdades, não apenas de erros de interpretação. Não é apenas 'obediência cega'. A autoridade, na verdade, é um atributo de pessoas que têm seu fundamento último num "ato de reconhecimento e de conhecimento: reconhece-se que outro está acima de nós em juízo e perspectiva e que, por consequência, seu juízo precede, ou seja, tem primazia em relação ao nosso próprio". ${ }^{50}$

Decorre do reconhecimento um ato, pois, da própria razão, que, tomando consciência dos seus próprios limites, atribui a outro uma perspectiva mais acertada. A autoridade é mais consagrada, 'sabe melhor'. "Sem dúvida que os preconceitos que implantam encontram-se legitimados pela pessoa." Legitimados racionalmente, pois a sua validez requer predisposição, convertendo-se posteriormente em preconceitos objetivos. ${ }^{51}$

A crítica romântica ao movimento racionalista defendeu a tradição como autoridade que nos determina o ser, de tal modo que nem a maturidade do ser humano se afasta completamente das prévias fundamentações recebidas tradicionalmente.

Não é por outra razão que Gadamer denomina a tradição como o fundamento de validez de vários fenômenos, como o costume, determinando amplamente as nossas instituições e comportamentos.

Por sermos históricos, o entendimento se subjuga à herança da tradição, inclusive no campo do conhecimento científico, no qual Gadamer entrevê que o distanciamento 'racional' do historicismo do ser ao afastar a tradição como um preconceito é apenas mais um preconceito:
A investigação espiritual-científica não pode ver-se a si própria em oposição pura e simples ao modo como nos comportamos com respeito ao passado na nossa qualidade de entes históricos. [...] Antes, encontramo-nos sempre em tradições, e esse nosso estar dentro delas não é um comportamento objetivador, [...] isso já é sempre algo próprio, exemplar e intimidante, um reconhecer-se $[\ldots] .^{52}$

\footnotetext{
${ }^{50}$ GADAMER, Hans-Georg. Verdade e método: traços fundamentais de uma hermenêutica filosófica. Tradução de Flávio Paulo Meurer. 3. ed. Petrópolis: Vozes, 1999. v. 1. p. 419.

${ }^{51}$ GADAMER, Hans-Georg. Verdade e método: traços fundamentais de uma hermenêutica filosófica. Tradução de Flávio Paulo Meurer. 3. ed. Petrópolis: Vozes, 1999. v. 1. p. 420.

${ }^{52}$ GADAMER, Hans-Georg. Verdade e método: traços fundamentais de uma hermenêutica filosófica. Tradução de Flávio Paulo Meurer. 3. ed. Petrópolis: Vozes, 1999. v. 1. p. 423.
} 
Na hermenêutica, diz Gadamer, a oposição abstrata entre tradição e investigação histórica (ciência do espírito) deve ser solucionada, pois no conhecimento da própria história se revela a conservação de elementos: importa em reconhecer o momento da tradição no comportamento hermenêutico histórico.

Uma vez reconhecido esse momento, parte-se para o outro polo da compreensão, fundado no destaque, feito pelo intérprete, na tradição recebida. Entende-se que o destaque é justamente a suspensão feita pela primazia da pergunta: abre-se a possibilidade de surgimento de interpretações. Pode ser entendido como a clareira de Heidegger, na qual se antevê o Ser, mas não o apreende.

A pergunta é, pois, imprescindível ao compreender, sendo que a resposta se delimita em decorrência da amplitude, maior ou menor, da pergunta feita. Essa é a premissa básica de que a verdade é relativa à verdade do método escolhido, assumidamente apenas parte da verdade total que, na perspectiva do Ser em Heidegger, não é alcançável.

A terceira variável é o momento da aplicação. A necessidade de aplicação ao presente do intérprete é estágio de toda compreensão: ela se subjuga à necessidade do intérprete em aplicá-lo à sua atualidade: a compreensão se subjuga à comparação dos elementos indicadores do texto com os da realidade atual (linguística, pois).

Segundo Gadamer, compreender o que alguém diz não é se deslocar para o outro e reproduzir suas vivências, mas pôr-se de acordo com a coisa, encerrando sempre um momento de aplicação. ${ }^{53}$

Disso, a história efeitual - a tradição nos determina a própria compreensão dela - como dialética, fusão de horizontes: o horizonte do texto e do intérprete (presente da aplicação). Todo esse processo de compreensão, para Gadamer, é linguístico. A linguagem é o meio em que se realiza o acordo dos interlocutores e o entendimento sobre a coisa. ${ }^{54}$

${ }^{53}$ GADAMER, Hans-Georg. Verdade e método: traços fundamentais de uma hermenêutica filosófica. Tradução de Flávio Paulo Meurer. 3. ed. Petrópolis: Vozes, 1999. v. 1. p. 559.

${ }^{54}$ GADAMER, Hans-Georg. Verdade e método: traços fundamentais de uma hermenêutica filosófica. Tradução de Flávio Paulo Meurer. 3. ed. Petrópolis: Vozes, 1999. v. 1. p. 559-560. 
De modo diferente pensa Emilio Betti, para quem somente a hermenêutica jurídica se caracteriza pelo momento de aplicação, ou seja, pela exigência jurídica necessária à tomada de posição frente a determinadas situações concretas (situações judiciárias) com algum fundamento democrático, o que pressupõe a atualização dos textos jurídicos a serem aplicados..$^{55}$

De acordo com a hermenêutica filosófica, no entanto, o momento da aplicação não é peculiar à hermenêutica jurídica, mas elemento necessário à própria compreensão do mundo em derredor do ser humano, a qual necessariamente lida com elementos da tradição (dogmáticos) e com os demais preconceitos do intérprete, perante situações presentes. São o que Gadamer denominou de situações hermenêuticas. ${ }^{56}$

De qualquer modo, porém, âmbito incontroverso da aplicação é o âmbito jurídico. Nele há necessidade de aplicação da interpretação obtida, o que será mais pormenorizado no capítulo seguinte.

Aqui resta analisar uma crítica de Habermas contra a teoria de Gadamer. Habermas analisa que Gadamer conclui a prioridade ontológica da tradição linguística em relação a todas as críticas possíveis. A sua leitura de Gadamer conclui que apenas se pode criticar as tradições específicas com base no fato de pertencermos ao contexto compreensivo da tradição de uma linguagem, pressupondo-se um consenso. ${ }^{57}$

No entanto, Habermas assevera que na perspectiva de uma hermenêutica profunda o consenso alcançado por meios aparentemente 'racionais' pode muito bem ser o resultado de uma pseudocomunicação. Redige que a mudança inconsciente dos paleo-símbolos, em uma mente de uma pessoa com patologia psiquiátrica, altera a sua própria vivência (confronto entre códigos públicos e o código privado dessimbolização). ${ }^{58}$

\footnotetext{
${ }^{55}$ BETTI, Emilio. Interpretação das leis e dos atos jurídicos. Tradução de Karina Jannini. São Paulo: M. Fontes, 2007. p. 11.

${ }^{56}$ GADAMER, Hans-Georg. Verdade e método: traços fundamentais de uma hermenêutica filosófica. Tradução de Flávio Paulo Meurer. 3. ed. Petrópolis: Vozes, 1999. v. 1. p. 578-579.

${ }^{57}$ HABERMAS, Jürgen. A pretensão da hermenêutica à universalidade. In: BLEICHER, Josef. Hermenêutica contemporânea. Tradução de Maria Georgina Segurado. Rio de Janeiro: Edições 70, 1980. p. 286-287.

${ }^{58}$ HABERMAS, Jürgen. A pretensão da hermenêutica à universalidade. In: BLEICHER, Josef. Hermenêutica contemporânea. Tradução de Maria Georgina Segurado. Rio de Janeiro: Edições 70, 1980. p. 270.
} 
Nessa hipótese é necessária a intervenção médica, especialmente por meio da compreensão cênica, para que haja a reconstrução de uma relação símbolocoisa patológica, com o fito de adequá-la à relação dita pública, e restabelecer-se a comunicação social com aquele indivíduo (reinserção). ${ }^{59}$

Assim, só acreditaria Habermas na força e verdade de um consenso racional precedente à compreensão que nos chega por intermédio da tradição linguística, caso se tivesse certeza de que não houve distorção ou qualquer imposição de força em nível social, o que é afastado pela hermenêutica profunda a qual analisa a comunicação distorcida.

O dogmatismo do contexto estaria não só sujeito à objetividade da linguagem em geral, mas também à repressividade de forças que deformam a intersubjetividade do acordo enquanto tal e que distorcem sistematicamente a comunicação cotidiana. "Por esse motivo, todo o consenso, como resultado de uma compreensão do sentido, é, em princípio, suspeito de ter sido imposto por meio da pseudocomunicação." 60

Diante das asserções de Habermas, podem ser relacionadas três soluções, restando impassível a teoria ontológica da compreensão de Gadamer, havendo apenas uma complementação deste por aquele.

Primeiramente, é de se questionar se Gadamer afirma o dogmatismo cego à tradição linguística ou apenas a indica como uma condição de possibilidade que limita a nossa compreensão de forma inconsciente.

Outrossim, pode-se dizer de Gadamer que é objetivo da hermenêutica tornar consciente a pré-compreensão (preconceitos 'bons' e 'maus' - os bons como condição de possibilidade da compreensão) para livrar a compreensão dos obstáculos impostos pela comunicação linguística.

${ }^{59}$ HABERMAS, Jürgen. A pretensão da hermenêutica à universalidade. In: BLEICHER, Josef. Hermenêutica contemporânea. Tradução de Maria Georgina Segurado. Rio de Janeiro: Edições 70, 1980. p. 272.

${ }^{60}$ HABERMAS, Jürgen. A pretensão da hermenêutica à universalidade. In: BLEICHER, Josef. Hermenêutica contemporânea. Tradução de Maria Georgina Segurado. Rio de Janeiro: Edições 70, 1980. p. 288. 
Entre esses, poderia figurar perfeitamente a preconizada 'distorção comunicativa' de Habermas, ou uma ideologia parcial (manifestação de força) subjacente à compreensão inicial (obscura) e preconceituosa.

O consenso de Gadamer não é verdadeiro, como critica Habermas. É o consenso possivel perante o contexto da finitude da linguagem humana e de sua perspectiva própria. Como visto, Gadamer não apregoa a existência de verdades absolutas, apenas verdades históricas, temporais, no contexto da finitude e incompletude humanas.

E esse contexto finito não se refere à aceitação cega de ideologias ou qualquer consenso tradicional, mas, antes, o máximo que se pode chegar a compreender perante a eliminação e complementação de todos os preconceitos tornados conscientes pela hermenêutica.

Pelo contrário: é dever hermenêutico eliminar todos os obstáculos à compreensão linguística, assumindo, porém,que essa, mesmo depurada, face à finitude humana, não pode ser objeto de avaliação como correta ou equivocada, mas algo como vigente, de acordo com o referido contexto.

Verifica-se que Habermas concorda com Gadamer, dizendo que a compreensão não é estanque; para ambos é possível o desenvolvimento de uma nova compreensão prévia, sendo a consciência da história efeitual a questão do ser em melhorar-se, e não propriamente da consciência. ${ }^{11} \mathrm{~A}$ relatividade da interpretação é, por isso, conclusão óbvia, sendo o processo de formação da pré-compreensão infinito e progressivo. ${ }^{62}$

Secundariamente, a dialética da pergunta e resposta em Gadamer demonstra muito bem o seu posicionamento zetético ante a tradição linguística (ademais, como sempre foi Heidegger em relação à fenomenologia), ao contrário do que

${ }^{61}$ HABERMAS, Jürgen. A pretensão da hermenêutica à universalidade. In: BLEICHER, Josef. Hermenêutica contemporânea. Tradução de Maria Georgina Segurado. Rio de Janeiro: Edições 70, 1980. p. 258.

${ }^{62}$ Interessante notar a aproximação de Karl Larenz: ele afirma que o entendimento prévio é suscetível sempre de retificação e o sentido de justeza é identificado somente no final de cada extração de sentido: seria a comparação entre os sentidos extraídos. LARENZ, Karl. Metodologia da ciência do direito. 4. ed. Lisboa: Fundação Calouste Gulbenkian, 2005. p. 292-293. 
apregoa Habermas em sua crítica ao dogmatismo do contexto. Tal dogmatismo nesses termos não é gadameriano.

Uma terceira solução é a de que a tradição subjuga a compreensão do intérprete do que seja a própria distorção comunicativa. Segundo o que pode ser interpretado da teoria de Gadamer, toda a realidade linguística ao nosso redor é entendida conforme a fusão horizôntica da tradição e do destaque: nesse contexto o que seja compreendido como distorção comunicativa no nível intersubjetivo é questionável (o que por sua vez Habermas não deixa claro).

Pode-se supor, por exemplo, que a distorção a que Habermas faz referência seja a comunicação possível entre os sujeitos em uma sociedade complexa. Dada a complexidade das sociedades contemporâneas, o consenso racional pressuposto é extremamente necessário, constituindo-se muitas vezes no reconhecimento racional referido por Gadamer: "Reconhece-se que o outro está acima de nós em juízo e perspectiva e que, por consequência, seu juízo precede, ou seja, tem primazia em relação ao nosso próprio". ${ }^{63}$

Nesse sentido, a questão de saber até onde a "repressividade de forças que deformam a intersubjetividade" pode ser identificada com exatidão, não se confundindo com o efetivo reconhecimento (de todo modo tácito) dos próprios sujeitos na relação, continua não esclarecida.

Essa análise do conflito entre dois grandes hermeneutas também veio a contribuir ao entendimento mais completo da teoria de Gadamer. A ligação com a legitimidade orçamentária deve ser explicada após esse primeiro passo, mas também depois de outro: a primazia da interpretação da Constituição.

\subsection{0 apelo a uma nova aplicação constitucional por meio da hermenêutica filosófica}

Foi visto que a compreensão do sentido dos textos se dá com a fusão horizôntica entre tradição e destaque (consciência da história efeitual). Assim é que a interpretação tida por determinada geração, conforme o dogmatismo da tradição

${ }^{63}$ GADAMER, Hans-Georg. Verdade e método: traços fundamentais de uma hermenêutica filosófica. Tradução de Flávio Paulo Meurer. 3. ed. Petrópolis: Vozes, 1999. v. 1. p. 419. 
(racional), destaque e pré-compreensão, não pode ser de nenhuma maneira rechaçada como equivocada, falsa. É uma das possibilidades interpretativas, detendo por isso legitimidade relativa ao tempo em que foi aplicada.

No que concerne aos textos jurídico-constitucionais, tal não é diferente. Pode-se asseverar a existência de uma exigência de decidibilidade peculiar ao exercício do Direito. E essa constitui fundamento do seu caráter hermenêutico:

A determinação do sentido das normas, o correto entendimento do significado dos seus textos e intenções, tendo em vista a decidibilidade de conflitos constitui a tarefa da dogmática hermenêutica. Trata-se de uma finalidade prática, no que se distingue das demais ciências humanas. ${ }^{64}$

Aqui, assume-se que o Direito lida com a interpretação e até mesmo com a ontologia da compreensão, porém diverge do modo como isso ocorre em outras Geisteswissenschaften, a exemplo da história e da filologia.

Porém, mesmo que seja vislumbrada a fase de aplicação em todas as atividades hermenêuticas, disso decorre a pretensão à universalidade da hermenêutica filosófica como ontologia da compreensão, na esfera jurídica há pelo menos duas peculiaridades apontadas como a possibilidade de heteronomia e a efetividade de certa pauta de direitos (teleológico).

E como a atuação jurídica atua de modo diferente da compreensão em geral, embora o momento aplicativo exista em ambos, é possível apontar outros caracteres que lhe são peculiares.

Necessário dizer, porém, que a compreensão jurídica e a compreensão em geral são logicamente imbricadas: quem está a interpretar o texto e a situação é um homem, o qual faz algo além de compreender em geral.

Primeiramente, na compreensão em geral o dogmatismo da tradição pode, quando identificado, ser rechaçado livremente. O dogmatismo legal, apesar da adaptação aos casos, nem tanto.

Em segundo lugar, a aplicação jurídica é heterônoma, o que requer a existência de fundamentos publicamente aceitos para que a decisão tenha eficácia

${ }^{64}$ FERRAZ JR., Tércio Sampaio. Introdução ao estudo do direito: técnica, decisão dominação. 4. ed. São Paulo: Atlas, 2003. p. 256. 
heterônoma. Isso, por garantia de ordem jurídica: a proibição de não influenciar a esfera alheia sem qualquer fundamento.

Aqui também se explica o dever de cuidado ao se afastar o dogmatismo jurídico, porque ele, em certo sentido, é um fundamento aceito racionalmente (embora de maneira presumida). Quanto mais descritível for uma norma válida, portanto, mais difícil propor a sua superação.

Em termos de norma como regra ou princípio, a regra, por possuir maior descritividade, possui uma trincheira apenas superável com argumentos consistentes e racionais e somente em casos-limite, todos a fundamentarem o surgimento de uma antinomia ou a criação de uma exceção.

Acompanhando o corte epistemológico do presente artigo, é importante considerar que o dogmatismo jurídico é uma espécie de tradição que chega ao intérprete judiciário por meio tanto da formação teórica quanto da experiência prática: a pré-compreensão do jurista é a formação dos dogmas aprendidos em uma vida de estudo e prática do Direito.

A tradição pode ser questionada, conforme a dialética de pergunta e resposta enaltecida por Gadamer, na medida em que um caso concreto reclame, por imperativos de decidibilidade, uma nova atualização (aplicação) dos textos normativos válidos.

Há as chamadas possibilidades interpretativas e por isso uma interpretação em certo contexto histórico, diante de determinada tradição e destaque, detém legitimidade porque aplicada ao presente, diante de elementos de fato e de regramento social.

Tal raciocínio deve ser aplicado no caso da interpretação jurídica em que a interpretação competente ganha status de vigência. Como determinada tomada de posição racional não pode ser considerada pior do que outra, a decisão judicial válida não pode ser afastada de plano, possuindo uma vigência enquanto a tradição jurídica for a mesma ou enquanto a compreensão dos fatos da vida relevantes reste inalterada.

De outro lado, como o jurídico é âmbito incontroverso do estágio da aplicação, servindo como tradição elementos de direito (fontes), deve ser questionado o seu modo quanto à esfera constitucional. 
Antes vale apontar os ensinamentos de Karl Larenz. Para ele, o processo de aplicação do direito envolve o sentido inicial (literal) e uma teia de interpretações diversas, com complementações e restrições de sentido. Para ele, inclusive, o momento de aplicação em verdade é de todo o compreender, pois o passado somente é entendido na sua continuidade com o presente. ${ }^{65}$

Mas o problema do Direito é a distância entre generalidade da hipótese e individualidade do caso concreto. Superar essa distância é a tarefa de concretização da norma, ${ }^{66}$ ao tempo em que se une ao princípio da igualdade: tratar os casos iguais de forma igual. ${ }^{67}$

As maneiras de aplicar o entendimento sobre os textos constitucionais são diversas, conforme se torne proeminente um dos possíveis aspectos de toda Constituição. Tomemos, porque são únicos em importância ao nosso estudo, o aspecto político e o aspecto jurídico.

No âmbito de carta eminentemente política, por dizer respeito à organização do Estado, seus deveres e prerrogativas correspondentes, a natureza da aplicação é política, mediante atos formais e materiais. Os atos formais correspondem aos atos introdutores de normas e os materiais aos atos de cumprimento efetivo, pelos entes competentes. ${ }^{68}$ Nesses últimos se abarcam somente o cumprimento por atos discricionários, por sua natureza política.

No âmbito de documento jurídico a ser aplicado pelos Tribunais, a aplicação é jurídica em razão da vinculação aos destinatários da interpretação (norma) construída pelo Judiciário ou aquiescida por ele. Os atos vinculados não possuem natureza política

${ }^{65}$ LARENZ, Karl. Metodologia da ciência do direito. 4. ed. Lisboa: Fundação Calouste Gulbenkian, 2005. p. 294-295.

${ }^{66}$ LARENZ, Karl. Metodologia da ciência do direito. 4. ed. Lisboa: Fundação Calouste Gulbenkian, 2005. p. 295.

${ }^{67}$ LARENZ, Karl. Metodologia da ciência do direito. 4. ed. Lisboa: Fundação Calouste Gulbenkian, 2005. p. 297.

${ }^{68}$ Vale apontar que não entendo, como Paulo de Barros Carvalho, os 'introdutores de norma’ como normas em si: são apenas textos dos quais se extrairão outras normas, diferentes das que fundamentaram o ato por assim dizer legislativo de introduzir norma (normas de competência). CARVALHO, Paulo de Barros. Curso de direito tributário. 19. ed. São Paulo: Saraiva, 2008. p. 56-57. 
(somente de forma indireta, porque o introdutor de norma é ato formal político), mas jurídica, tanto que o seu controle pelo Judiciário é incontroverso. ${ }^{69}$

O âmbito de aplicação jurídica é deveras amplo: pode ser autônoma, em vista do cumprimento espontâneo do destinatário, ou heterônoma, em vista da necessidade de manifestação do Judiciário. Conforme seja essa necessidade, haverá qualificação da decisão: se apenas formal, é indicativa; se material, coativa.

Diante da classificação exposta, que merece maiores digressões, incabíveis, porém no presente trabalho, analise-se o cumprimento das normas constitucionais de dever do Estado com as importantes observações traçadas pela hermenêutica filosófica de Gadamer, com especial proeminência do estágio de aplicação da interpretação a ser feita pelo administrador e pelo jurista, uma vez compelido a analisar os processos de preferência realizados por aquele no âmbito do Orçamento Público.

Primeiramente, saliente-se que o Orçamento Público é um ato de cumprimento constitucional formal, ou seja, um introdutor de normas. O seu cumprimento, porém, abarca as duas naturezas: política e jurídica.

A política se limita à discricionariedade orçamentária. Mas esta não se dá de forma absoluta, e sim em graus, conforme o momento de preferência administrativa acerca de determinadas necessidades e ao momento de execução orçamentária, em se tratando de indiferente jurídico - escolha política dos meios. ${ }^{70}$

O cumprimento jurídico pode ser de dois matizes: autônomo, quando a Administração, com razoabilidade e proporcionalidade, cumpre os dispositivos orçamentários conforme a necessidade da população governada e a prévia estatuição; e heterônomo, quando o Poder Judiciário, nos limites de sua legitimidade discursiva, impõe àquela o cumprimento constitucional das rubricas orçamentárias.

${ }^{69}$ MELO, Celso Antônio Bandeira de. Curso de direito administrativo. 18. ed. rev. e atual. São Paulo: Malheiros, 2005. p. 399. A falta de apreciação subjetiva caracteriza a falta de opção política em termos de ato vinculado.

${ }^{70}$ Cf. ANJOS, Pedro Germano. Os graus da discricionariedade da administração pública no âmbito do direito orçamentário. In: ENCONTRO PREPARATÓRIO PARA O CONGRESSO NACIONAL DO CONPEDI, 27., 2008, Florianópolis. Anais... Florianópolis: Fundação Boiteux, 2008. No prelo. 
Note-se que a qualificação do cumprimento em constitucional muitas vezes depende de uma acepção judiciária. Mas desde logo se ressalte: não quanto ao modo - avaliação da decisão sobre a qualidade do cumprimento -, mas quanto à decisão de cumprir ou não cumprir - avaliação da avaliação de decisão sobre o cumprimento -, a qual decorra das escolhas constitucionais, como se verá adiante.

Não se pode olvidar que a acepção judiciária do que é exigido a par de determinadas regras e princípios constitucionais desenvolve-se com o tempo, na medida em que os dispositivos são aplicados. É o fenômeno do preenchimento de sentido das cláusulas abertas do direito, como lembra Karl Larenz:

Essas pautas alcançam o seu preenchimento de conteúdo mediante a consciência jurídica geral dos membros da comunidade jurídica, que não só é cunhada pela tradição, mas que é compreendida como estando em permanente reconstituição. $^{71}$

A noção, portanto, do que seja constitucional é produto da interpretação do órgão incumbido de realizar o cumprimento heterônomo da Constituição. E curioso que o seu entendimento também incentiva o sentido do cumprimento autônomo. Logo, o Judiciário, que tem legitimidade para ordenar indiretamente a conduta (por meio do incentivo a determinado sentido do comportamento autônomo), também possui legitimidade hermenêutica para, ponderando os interesses em jogo, realizar juízos racionais do que deve ser cumprido ou afastado. ${ }^{72}$

\subsection{A legitimidade da indicação orçamentária}

“Os dados são vistos num contexto histórico que se refere à autocompreensão dos grupos sociais que, por sua vez, é determinada pela tradição." ${ }^{73} \mathrm{O}$ conceito de necessidades públicas não é estanque, quer temporal, quer espacialmente.

\footnotetext{
${ }^{71}$ LARENZ, Karl. Metodologia da ciência do direito. 4. ed. Lisboa: Fundação Calouste Gulbenkian, 2005. p. 311.

72 ALEXY, Robert. Constitucionalismo discursivo. Tradução de Luis Afonso Heck. Porto Alegre: Livraria do Advogado, 2008. p. 110-113.

${ }^{73}$ BLEICHER, Josef. Hermenêutica contemporânea. Tradução de Maria Georgina Segurado. Rio de Janeiro: Edições 70, 1980. p. 353.
} 
Por isso, a lei orçamentária é reduto de uma peculiar vontade política do Estado: é por ela que o governo indica o que entende por necessidade primária e mais urgente e por necessidades subordinadas.

Que a eleição das necessidades a serem satisfeitas por determinado governo é de natureza política, não há a menor dúvida. O decisivo é a perspectiva que o Poder Judiciário deve ter perante a invocação constitucional de deveres estatais, a eleição propriamente dita das necessidades (in concreto) e o modo como se dá a execução efetiva das rubricas orçamentárias, se atinentes aos dispositivos e às necessidades factuais (também in concreto).

Vê-se que o primeiro mediador do fenômeno de cumprimento dos deveres constitucionais é a Administração Pública. Após, o Poder Legislativo referenda e altera a proposta orçamentária. O Poder Judiciário, por sua vez, a investigar e determinar o cumprimento razoável das leis e da Constituição, pode atuar em duas frentes.Primeiramente, na avaliação da avaliação constitucional dos outros poderes sobre as necessidades que devem levar a cabo (nível abstrato das leis orçamentárias).Secundariamente, na avaliação da avaliação factual do Executivo, quanto aos motivos de não satisfação das necessidades previstas no âmbito orçamentário (previsão abstrata). Tal frente de combate pressupõe o poder de controle efetivo das despesas orçamentárias quando verificado processualmente (questão de prova) que há necessidades constitucionais factuais da comunidade desatendidas, preteridas em relação a necessidades tidas por secundárias.

Sobre a classificação das necessidades públicas constitucionais, pode-se dizer que se dividem em necessidades stricto sensu, úteis e de possibilidade regrada. ${ }^{74}$ Trata-se de classificação abstrata, mas atual no sentido da conjuntura político-econômica brasileira.

O motivo de tal classificação e o seu imbricamento com a lei orçamentária e os deveres estatais constitucionais são mais bem explicitados quando analisamos a hermenêutica, notadamente, a filosófica de Gadamer.

\footnotetext{
${ }^{74}$ Os fundamentos para tal divisão podem ser encontrados em ANJOS, Pedro Germano. Natureza das escolhas orçamentárias: por uma classificação constitucional das necessidades públicas. In: ENCONTRO PREPARATÓRIO PARA O CONGRESSO NACIONAL DO CONPEDI, 27., 2008, Florianópolis. Anais... Florianópolis: Fundação Boiteux, 2008. p. 2375-2394.
} 
Sobre hermenêutica, diz Josef Bleicher que

As ciências hermenêuticas ajudam à preservação e extensão da comunicação sobre o sentido da vida, os objetivos do desenvolvimento sócio-político, os estilos de vida públicos e privados, etc., tornando acessível o sentido de textos e ações e, por sua vez, antecipando ou projetando possíveis formas de (melhor) vida. ${ }^{75}$

Do excerto pode-se entender que a ciência hermenêutica auxilia a compreensão, pelo homem, do seu mundo, auxiliando-o na melhora da qualidade de vida. Tal entendimento se coaduna com a perspectiva gadameriana sobre o estágio da aplicação, em toda compreensão linguística.

A presença da comunidade, da tradição, do contexto e do dogmatismo são vozes que falam ao intérprete do seu passado e do seu presente, os quais são somados ao seu destaque da tradição (em si modificados, pois) e repassados para o futuro.

Gadamer aduz que a compreensão sempre possui uma esfera aplicativa, pois sempre significa uma tomada de decisão. Há exigência ontológica quanto a esse modo de compreender pelo intérprete, interpretação que será determinante para outrem sempre que existir a possibilidade de exigência heterônoma (característica da Jurisdição).

Pode-se falar que o intérprete compreende um texto (o qual também forma a tradição) a partir do contexto recebido pela tradição em geral, mas por meio do modo de aplicação ao presente: conforme as suas necessidades de variada ordem (confundidas com interesse), por vezes inconscientemente.

Quanto às necessidades públicas, o administrador e o corpo legislativo interpretam o texto constitucional de deveres estatais a partir das necessidades sociais do seu contexto, conforme cheguem a eles por meio da comunidade governada. ${ }^{76}$

Porém, com a falta desse trabalho interpretativo engajado com as normas constitucionais, caberia ao Judiciário indicar quais as necessidades que devem ser buscadas (mediante a perspectiva constitucional aplicada ao presente), porém, respeitando a lei orçamentária que assim cumpre esse rol.

\footnotetext{
${ }^{75}$ BLEICHER, Josef. Hermenêutica contemporânea. Tradução de Maria Georgina Segurado. Rio de Janeiro: Edições 70, 1980. p. 353.

${ }^{76}$ A referência é aos cargos, não às pessoas em si. Trata-se de análise ideal, não material.
} 
'Respeito do Judiciário' pressupõe a defesa, por este, da lei orçamentária não cumprida, por caracterizar o descumprimento ou desvio de finalidade administrativa, fundado na interpretação contraditória do administrador ao longo do tempo: se se fala em aplicação, pressupõe-se vigência daquela interpretação, vigência essa coincidente com o exercício da lei orçamentária, salvo quando haja mudança brutal da situação de fato, a requerer outra aplicação. ${ }^{77}$

Na superação das rubricas orçamentárias, pois, há atividade de superação de regras. E as regras apenas podem ser superadas caso o âmbito factual regrado (natureza singular do presente) reclame uma exceção ou desvirtue algum elemento essencial do descritor da norma (caso de inaplicabilidade).

Esta, a segunda frente de combate do Judiciário: não havendo a constatação da efetiva despesa no mundo dos fatos ou não havendo qualquer circunstância material que justifique a superação da regra orçamentária, o Executivo não pode se imiscuir de cumprir os dispositivos legais orçamentários.

As frentes de combate (avaliação da avaliação) ${ }^{78}$ se justificam em decorrência de uma primazia das escolhas orçamentárias de ordem hermenêutica. Os poderes executivo e legislativo detêm essa função constitucional de interpretar, por um lado, a extensão de seus deveres, a partir dos dispositivos constitucionais aplicáveis; de outro lado, as necessidades da comunidade governada, planejando a sua satisfação por meio das receitas públicas.

Trata-se do momento de aplicação das normas constitucionais. Subsidiariamente, pois, o judiciário deve intervir, sempre que essa dupla tarefa hermenêutica se revele equivocada, oportunidade em que fará a sua aplicação hermenêutica da Constituição e da satisfação das necessidades, sempre respeitando o orçamento consoante com a divisão proporcional dos gastos e deveres constitucionais do Estado.

${ }_{77}$ ÁVILA, Humberto. Teoria dos princípios: da definição à aplicação dos princípios jurídicos. 7. ed. São Paulo: Malheiros, 2007. p. 103.

${ }^{78}$ Expressão de ÁVILA, Humberto. Teoria dos princípios: da definição à aplicação dos princípios jurídicos. 7. ed. São Paulo: Malheiros, 2007. p. 174. 


\section{Considerações finais}

No presente trabalho monográfico foi visto que a aplicação do direito detém uma base hermenêutica fundamental, dado que a norma possui um conceito semântico. Em vista da falta de correspondência biunívoca entre dispositivo e norma, o aplicador do direito necessariamente atua na reconstrução do significado das mensagens normativas, solucionando a distância ontológica texto-norma e a distância do objeto dessa relação conduta geral-conduta fática.

Assim, pode ser dito que a interpretação no direito é de duplo teor: de um lado, interpretar o texto normativo para originar o functor deôntico $;^{79}$ de outro, interpretar a linguagem referente aos fatos da vida e à estrutura social (natureza das coisas).

Como marco teórico acerca da hermenêutica, Hans-Georg Gadamer fornece, por meio de sua teoria de hermenêutica filosófica, importantes contribuições para a aplicação interpretativa do direito. No decorrer deste estudo, foram vistos institutos fundamentais de sua complexa teoria, dando-se ênfase para a estrutura dialógica da compreensão, a fusão horizôntica entre tradição e destaque do intérprete e, logo, as variáveis da compreensão segundo esse processo de fusão.

O estágio de aplicação foi analisado com a importante conclusão de que o direito se refere a uma necessidade de aplicação ao presente dos textos normativos, ao tempo em que se suspende o processo de formação da pré-compreensão: é a exigência de decidibilidade, mesmo com a cognição limitada (e sempre é limitada, em vista da finitude humana). A certeza do direito e a cognição exauriente são meras ficções.

Atrelada a essa finitude, está a relativização das verdades jurídicas: a verdade a que chega um magistrado quando decide é uma verdade relativa ao processo, à natureza singular do presente e à pré-compreensão do significado dos princípios e regras vigentes à época. É verdade histórica, temporal.

\footnotetext{
${ }^{79}$ ALEXY, Robert. Teoria dos direitos fundamentais. Tradução de Virgílio Afonso da Silva. São Paulo: Malheiros, 2008. p. 54-55. (Teoria e Direito Público). Sobre elementos deônticos, WRIGHT, Georg Henrik Von. Norma y accion: una investigación lógica. Tradução de Pedro Garcia Ferrero. Madrid: Tecnos, 1970. p. 167-171.
} 
Sobre a atividade hermenêutica da aplicação do direito, foi visto que pode ser atividade autônoma (destinatário) e heterônoma (judicial), sendo que, na aplicação heterônoma, o magistrado decide e preenche o significado das cláusulas abertas do direito, servindo a sua decisão, ademais de decidir o caso em si, como um elemento formador da pré-compreensão dos destinatários das normas e da própria jurisprudência.

Logo, o Judiciário tem legitimidade para ordenar indiretamente a conduta (por meio do incentivo a determinado sentido do comportamento autônomo), bem como legitimidade hermenêutica para, ponderando os interesses em jogo, realizar juízos racionais do que deve ser cumprido ou afastado ${ }^{80} \mathrm{em}$ um processo contínuo e progressivo.

De tais considerações sobre a hermenêutica de Gadamer e o estágio de aplicação no direito, podem ser referidas algumas considerações sobre a legitimidade do planejamento orçamentário. Isso porque a aplicação jurídica no seu âmbito pode ser autônoma e heterônoma, nos mesmos moldes das normas em geral.

Outrossim, trata-se de hermenêutica constitucional, vez que as necessidades públicas como objeto de deveres do Estado estão previstas em nosso documento jurídico maior.

A força constitucional de imposição de satisfação, pelo Estado, de determinadas necessidades é o ponto de partida para a interpretação normativa realizada pelos administradores e legisladores, ao perfazerem a lei orçamentária. Em seu bojo recorrem a escolhas, em vista da interpretação dos fatos sociais de necessidade e de uma hierarquia de prioridades (o que se aproxima com a legitimidade democrática do governo eleito, se esse seguir a sua proposta eleitoral).

Esta, a legitimidade hermenêutica das escolhas orçamentárias, deve se referir a uma interpretação razoável e proporcional da realidade fática da comunidade considerada, bem como da realidade normativa sobre o que está obrigado o Estado frente a tais necessidades (a hierarquia das prioridades não pode contrariar o entendimento racional da Constituição Federal de 1988).

\footnotetext{
${ }^{80}$ ALEXY, Robert. Constitucionalismo discursivo. Tradução de Luis Afonso Heck. Porto Alegre: Livraria do Advogado, 2008. p. 110-113.
} 
Essas interpretações autônomas (porque aplicação jurídica pelos destinatários) podem, inclusive, sofrer avaliação judicial, já que não se pode se afastar irracionalmente da realidade fática (proibição ao absurdo), nem se pode hierarquizar de maneira desproporcional as prioridades a serem satisfeitas. Tal é o novo controle de legalidade dos atos administrativos, o qual, acompanhando o preenchimento de significado do princípio da legalidade (ao incluir-se eficiência), sobrepuja o simples controle formal.

A hermenêutica filosófica, ademais, propicia o entendimento de que a verdade das escolhas orçamentárias deve se referir ao momento em que foram produzidas, devendo ser alterada somente quando a tradição linguística mude substancialmente (e não por simples vontade política) ou quando a situação de fato reclame outra aplicação hermenêutica.

Revela-se, aqui, um fundamento importante para um possível controle judicial das escolhas orçamentárias (e consequentes políticas públicas), com direção à proteção das interpretações já preconizadas nos documentos orçamentários, impedindo a sua mudança por qualquer razão.

Logo, pode-se dizer que a teoria de Gadamer sobre a ontologia da compreensão fundamenta hermeneuticamente a tomada de posição nas escolhas ínsitas das leis orçamentárias. Preconiza-se, assim, a sua proteção (inclusive judicial), uma vez mantido o contexto de sua formulação.

Trata-se de aplicação constitucional das mais importantes, por se referir à satisfação de necessidades públicas previstas na Constituição de 1988. O respeito ao consenso (dogmatismo da tradição), em bases racionais, é o que descreve a hermenêutica filosófica e, diante da organização prévia que a atuação do Estado deve possuir, é respeito o qual deve ser preconizado pela aplicação jurídica, autônoma ou heterônoma. Isso, com vistas à melhoria da pré-compreensão sobre a eficiência estatal e a sua efetividade em prol das necessidades que a Constituição comete às funções essenciais do Estado de Direito. 


\title{
The hermeneutic filosophy of Hans-Georg Gadamer and the budget law's choices of public policies
}

\begin{abstract}
The paper work aim to analyze the exercise of State's duties in order to attendant public needs exposed at the National Brazilian Constitution of 1988, through constitutional and budgetary ruled choices, exposing political options related to Executive's Power of any federal unit. For this objective, it's required the methodological mark of Hans-Georg Gadamer and its comprehension ontology. The consequences of this clarification are variable, being priority the theoretic and pragmatic assumption that the comprehension of constitutional texts happens through horizontical fusion between tradition and its suspension (historical effect sense), with the important application stage. Therefore, this stage, that is done by the administrator and the judge that have contact with his budgetary choices, it's essential for the correct planejament and consecution of public policies. Also, it's remarkable the comparison of interpretation relativity (Gadamer) with the constitutionals rights relativity (Robert Alexy), with important consequences related to budgetary choices. The original perspective of this paper, then, is essential to embase the judicial and social control of imprescindible State's duties and public gasts and also the respect of budget law.
\end{abstract}

Keywords: Hermeneutic filosophy. Jurisprudence interpretation. Budgetary choices. Public policy considerations. Budget law.

\section{Referências}

ALEXY, Robert. Constitucionalismo discursivo. Tradução de Luis Afonso Heck. Porto Alegre: Livraria do Advogado, 2008.

ALEXY, Robert. Teoria dos direitos fundamentais. Tradução de Virgílio Afonso da Silva. São Paulo: Malheiros, 2008. (Teoria e Direito Público).

ANJOS, Pedro Germano. Natureza das escolhas orçamentárias: por uma classificação constitucional das necessidades públicas. In: ENCONTRO PREPARATÓRIO PARA O CONGRESSO NACIONAL DO CONPEDI, 27., 2008, Florianópolis. Anais... Florianópolis: Fundação Boiteux, 2008. p. 2375-2394. 
ANJOS, Pedro Germano. Os graus da discricionariedade da administração pública no âmbito do direito orçamentário. In: ENCONTRO PREPARATÓRIO PARA O CONGRESSO NACIONAL DO CONPEDI, 27., 2008, Florianópolis. Anais... Florianópolis: Fundação Boiteux, 2008. No prelo.

ÁVILA, Humberto. Teoria dos princípios: da definição à aplicação dos princípios jurídicos. 7. ed. São Paulo: Malheiros, 2007.

BALEEIRO, Aliomar. Uma introdução à ciência das finanças. 16. ed. rev. e atual. por Dejalma de Campos. Rio de Janeiro: Forense, 2006.

BETTI, Emilio. Interpretação das leis e dos atos jurídicos. Tradução de Karina Jannini. São Paulo: M. Fontes, 2007.

BLEICHER, Josef. Hermenêutica contemporânea. Tradução de Maria Georgina Segurado. Rio de Janeiro: Edições 70, 1980.

BORGES, José Souto Maior. Introdução ao direito financeiro. São Paulo: M. Limonad, 1998.

CARVAlHO, Paulo de Barros. Curso de direito tributário. 19. ed. São Paulo: Saraiva, 2008.

DWORKIN, Ronald. Levando os direitos a sério. Tradução Jefferson Luiz Camargo. São Paulo: M. Fontes, 2007.

DWORKIN, Ronald. O império do direito. Tradução de Jefferson Luiz Camargo. São Paulo: M. Fontes, 2007.

FERRAZ JR., Tércio Sampaio. Introdução ao estudo do direito: técnica, decisão dominação. 4. ed. São Paulo: Atlas, 2003.

GADAMER, Hans-Georg. Verdade e método: traços fundamentais de uma hermenêutica filosófica. Tradução de Flávio Paulo Meurer. 3. ed. Petrópolis: Vozes, 1999. v. 1.

HABERMAS, Jürgen. A pretensão da hermenêutica à universalidade. In: BLEICHER, Josef. Hermenêutica contemporânea. Tradução de Maria Georgina Segurado. Rio de Janeiro: Edições 70, 1980.

HEIDEGGER, Martin. Tempo e ser. 3. ed. Petrópolis: Vozes, 2008. (Pensamento Humano). 
KELSEN, Hans. Teoria pura do direito. 6. ed. Tradução de João Batista Machado. São Paulo: M. Fontes, 1998.

LARENZ, Karl. Metodologia da ciência do direito. 4. ed. Lisboa: Fundação Calouste Gulbenkian, 2005.

MELO, Celso Antônio Bandeira de. Curso de direito administrativo. 18. ed. rev. e atual. São Paulo: Malheiros, 2005.

PALMER, Richard E. Hermenêutica. Tradução de Maria Luisa Ribeiro Ferreira. Lisboa: Edições 70, 2006. (O saber da filosofia).

RICOEUR, Paul. Existência e hermenêutica. In: BLEICHER, Josef. Hermenêutica contemporânea. Tradução de Maria Georgina Segurado. Rio de Janeiro: Edições 70,1980 .

RICOEUR, Paul. Teoria da interpretação: o discurso e o excesso de significação. Tradução de Artur Morão. Lisboa: Edições 70, 1980.

ROSS, Alf. Direito e justiça. Tradução de Edson Bini. São Paulo: Edipro, 2000.

STEIN, Ernildo. Compreensão e finitude: estrutura e movimento da interrogação heideggeriana. Ijuí, RS: Unijuí, 2001. (Ensaios: política e filosofia).

WRIGHT, Georg Henrik Von. Norma y accion: una investigación lógica. Tradução de Pedro Garcia Ferrero. Madrid: Tecnos, 1970.

\section{Agradecimento}

Agradeço aos meus pais pelo apoio incondicional e pelos ensinamentos de honestidade e retidão em todos os afazeres da vida. E em especial, à minha noiva pela abnegação e ternura sempre constantes. 
